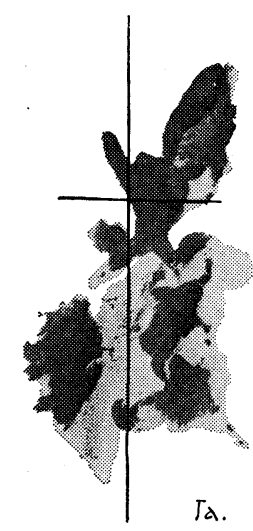

\title{
私の筋肉研 究
}

\section{I. 筋肉の研究へ}

丸山 私が江橋先生の拉仕事を初めて知ったのは, アセチルコリンの合成系 ${ }^{(1,2)}$ についてだと思いますが, 筋肉の研究はそこから始められたのでしょらか。

江橋 いわゆるコリンアセテラーゼを研究したので すが，ねらいは神経ではなくやはり筋肉で，熊谷洋先生 に平滑筋を電気生理的な方法でやれといわれたことから です.というのは，当時としては電気生理が学問の基礎 であるといら考え方だったわけで，骨格筋や神経につい てはきちんとした仕事があるが，平滑筋についてはほと んどなかったからなのです，材料は子宮の平滑筋ですが， これは熊谷先生が子宮を研究して扣られたためでした。 なにしろあの食糧欠乏の時代ですから，仕事よりもメリ ケン粉を焼いたり鞉の裏を直したりしているほうが多か ったのです，そんなことをしているらちに，1949年に病 気になりました. 1950年（昭和 25 年）の夏ごろから学校 へ出始めたのですが，実はそのとき私の大きな転回点に なる論文を 3 つ読んだわけです. 1つが Szent-Györgyi の 1947 年版の海賊版で，きたないゲラ刷りのプリント “Chemistry of Muscular Contraction”です. そのと きは非常に感激しましたが，技とらく，これを当時読ん だ人は皆同じだったと思います.もら 1 つは，1950 年の 秋に公衆衛生院で読んだ Hodgkin-Katz の論文です. つまり, 電気現象はナトリウムに依存するという非常に 素朴な実験だったと思うのですが，電気生理学を始めよ らかと思っていたところだったので非常なショックを受 けたわけです。それで, 熊谷先生に “すら電気生理学は
（語り手）江 橋 節 郎 Setsuro EBASHI 東京大学医学部楽理学教室

(聞き手) 丸 山 工 作 Koscak MARUYAMA

\section{（聞き手） 丸 エ 工 作 Koscak MARUYAMA
京都大学理学部生物物理学教室}




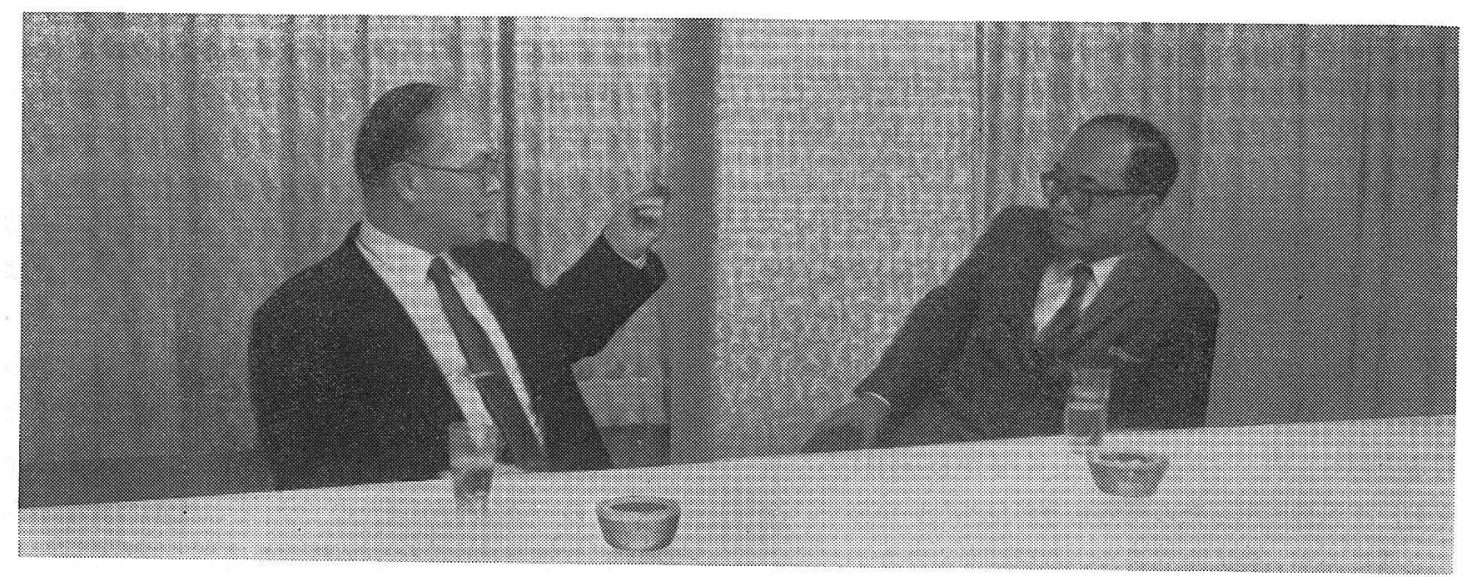

江 橋 節 郎氏

丸山工作氏

きかけるわけですが。

江橋 それはそうです. ですから，Burn の説が完 全に無意味だといい切ってよいかどうか, いまであ疑っ ているのです。むしろ, もら少し先までいくと, 平滑笳 のオートレギュレーションのよらなるのの中にアセチル コリンが登場するかもしれない。これは，いまでもまだ 決着がついていない問題です.

丸山 その当時は, CoA に関してはとの程度ご存じ でしたか。

江橋 アセチルコリンの合成に関与することはわか っていたのです. その点で1つ申したいのは，アセチレ ーションには cofactor が必要であるということの最初 の発見は, 括そらく Feldberg あるいは Nachmansohn であり, Lipmann ではないということです.つまり, CoA はコリンアセチラーゼについて発見されたわけです. 私も不純な $\mathrm{CoA}$ をなんとか自分でつくったものです. 当時は教室でイヌをさかんに使っていましたので，その 肝臓をもらって CoA の抽出を試みたわけです．拉恥ず かしい話ですが，「生化学実験法」の中に私が CoA の抽 出法を書いて洛ります。

丸山 ATP のナトリウム程のつくり方として， こ ねてつくる話を同じ本に江橋先生が書かれていますね. いまは昔がたりになってしまっていますが。

江橋私は生化学のオーソドックスな教育を受けて おりませんから，アセチルコリンで CoA を知り，CoA で Lipmann を知って, それから有名な ATP の総説に 戻ったわけです，そこでえらい人だなと感じたわけです。

\section{II. 弛 緩 因子}

丸山 コリンアセチラーゼ, つまりアセチルコリン をつくる酵素系の研究をして招られたことと，1954年で しょらか, 藤田さんという方といわゆる弛緩因子の研究
をなさったこととの関係をらかがいたいと思いすす。

江橋 それは, Szent-Györgyi のあの本で非常に影 響を受けて，やりたいと思っていたわけです。

丸山しかし, Szent-Györgyiは, 収縮系に関して はずいぶん強調しましたが，弛緩のことに関しては，例 の $0.6 \mathrm{M} \mathrm{KCl}$ に拈けるアクトミオシンのATPによる解 離以外は，1つもあの本には書いてなかったのですが.

江橋結局, 平滑筋を使って筋肉に興味をもったの はどうしてアセチルコリンで筋肉が縮さのかという問 題ですね.これをするためには収縮系の勉強をしなけれ ばいけないだろうと思い，そのときは収縮系の研究をす るつもりは毛頭なかったのですが，若いときのトレーニ ングの意味を兼ねて勉強を始めたのです，そのときに田 藤君がきて，一緒にすることになったわけです(3). 生化 学の方とは逆かもしれませんが, Szent-Györgyi がちょ と Chemistry of Muscular Contraction の最後のア ペンディクスに，グリセリン筋（筋肉の束をグリセリン につけるだけのこと）について書いているのをみて, こ れならわれわれ薬理の者にもたいへん楽なシステムだと いらことで始めたわけです。

丸山＼cjkstart藤田さんはどらいう方ですか。

江橋産婦人科の持医者さんです、いまでは医学部 の基礎はほとんど完全に大学院制になりましたが, 当時 はまだ学位論文制が残っていて，熊谷先生を頼って来た わけです。しかし，いわゆるティーテル取りというよう な人とは違って，熱心なだけでなく，研究者としての勘 をもった人でした，それに外科出身ですので，私と違っ て大変器用で, 本当に助かりました，彼が来なかったら， あの仕事は始められなかったと思います。

丸山 和宅の奥さんもそのころ拈いでになったので しょう.

江橋 Wや，らちのは 1,2 年あとです。しかし， 
終わりのころは重なっています(4). 藤田君の仕事につい ては能谷先生に全部任せられていたので, 自分で研究し たいと思っていたことをしてもら拉らといらわけでした。 最初, 藤田君は摘出した生きた筋を使ったオーソドック スな薬理の仕事をかなりされたわけですが，材料をグリ セリン筋にか京，アセチルコリンなどの薬のかわりに ATP をかけて収縮をみるといらわけです，ところが， 収縮したものからATP を除いたら収縮したのがもとへ 戻ると思ったのですが戻らない、いまからみればあたり ま充，不思議に思ったのは考方方が足りないからで，ほ んとうにわかった人ならそらいら疑問をもたない。

丸山 ATP を除いても縮みっぱなしで, あれは不 思議ですね.

江橋、ほんとうに不思議なのか, 不思議と思うほう が馬鹿なのかわかりませんが，特そらく私の場合は馬鹿 だった洼らなので，そこで研究を始めたのでしょう。わ れわれが最初にアクトミオシン抽出を藤田君などとやっ たのは1951年で, グリセリン筋で本格的に始めたのは19 52 年の中ごろです,

そうこうしているらちに, 1951 年の Bozler の論文を 教えられました，Bozler によると，ATPをたくさん加 えると弛緩するというのですが，追試してみるとそのと 蚛り弛緩する。ATPによって弛緩するというけれど, ATP の純度が問題なのではないか. 不純なときは縮ん で, 純粋なときは伸びるのではないかと考党て, 純粋な ATP をつくろらと一生懸命苦労しました! ATP をつ くる活うは私と家内とでしたわけです。藤田君は朝から 晚までグリセリン筋をつくっては縮ませていた。よい ATP なら他緩すると思ったときもありますが，結局と れはだめとわかり，ほんとらにその仕事をやめよらかと 思ったくらいです.

そのときに気がついたことは,プッシュなグリセリ ン筋は弛緩しやすいことで，これは Bozler も書いてお ります。少し古くなると驰緩しにくくなる、そこで、こ れはたしかに筋肉の中に何かある, もら一度実験してみ ようと,だいぶいや気がさしていた藤田君を説得して, 筋肉の抽出液をつくってそれをかければ䟝緩するのでは

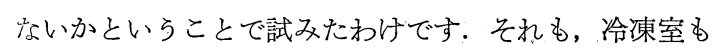
冷凍遠心機るないから，全部室温で行なったのです。，そ れがか兄ってょかったのでする。冷凍室で行なったら上 澄と沈椬とが簡単に分かれてくれなかったと思います。 その上澄をとってATP をいっしょに入れたら，みごと
飞弛緩したのです.それが 1952 年の終わりごろです.

丸山藤田さんの学位論文かどうか知りませんが, 雑誌に出たのは 1954 年ですね ${ }^{(3)}$.

江橋彼の学会報告は 1953 年ですが，初めて成功 したのは 52 年の終わりごろです，それで，そのときは ちょっと手ごたえがあった感じでかなりニコニコしてい ましたね. そのうちに Bendall の報告を知り，それから 逆に Marsh の研究を知ったのです. Bendall の論文は 1952年に出ているのですが, 1953 年の 3 月か 4 月にな って，その Nature がきたのです、それを熊谷先生がみ つけて，江橋君のいっている仕事と同じことをやってい るのがあるぞというので，仰天しましてね．しかし本当 のことをいうと、そのときはあまり悲観しなかったです 权. そのころは，外国に対してやたらとインフェリオリ ティ・コンプレックスが強かった時代でしたから，遅か ったにせよ，まあまあ同じレベルのことをしていたとい うので, むしろ嬉しかった. 要するに, コロンブスの再 発見で,つまらない話なのです，しかし，カルシウムを 入れるとピンと収縮するということも，Bendall の報告 を知る前に気がついていました。

丸山 そのカルシウムのことを技気づきになったの はなぜですか.

江橋 カルシウムと思ったのですね(笑)，そのとき 使ったカルシウムの濃度は非常に高いもので, 1 ミリモ ルでしたが，と汭くカルシウムは生理学者の常識でし よう. 生化学の人なら考皃なかったでしようが. カルシ ウムを入れればピンと上がるはずだといって実験したら そらなったので, あまりるのと動じない藤田君が感心し てくれたことを覚えています。

丸山 それは藤田さんの 1954 年の日本語の報文 ${ }^{(3)}$ に出ていますか。

江橋出ています、はじめは欧文で書くつもりでい たのですが，そのころは非常に誇り高かったので, Bendall の報告がある以上いまさらという気持で, そのまま 書かなかったのです。

丸山 英語も下手だったのではないですか(笑).

江橋皆さんがこの仕事をいわゆる本邦初演の、イ ミテーションではないと認めてくださったのは, 名取教 授の“筫肉の集い”といら同好者の集まりで，1958年の 初めごろからその話をする機会があったからです，その ときに本気で続けてするつもりであったかどらか，いま になると自分でもわかりません，午のあと家内が学位論 文の研究として藤田君のつづきをやったわけですが，そ， の間に扡緩因子についての論文がどんどん出てきました。 
丸山 例のクレアチンキナーゼとか, ミオキナーゼ といらのはあとだったかもしれませんが，1953年から54 年にかけていくつか出ましたね.

江橋 そうです. それは Bozler の考光方，ATP が 多いと弛緩するといらことと一致するわけです。それで 性生体の中で ATP が変わるかといらと，これは変わら ないから困るわけで…...

丸山 問題は例の Kielley-Meyerhof ATPase とい う粒子のことです。忘れましたが，フラクションのA， Bといわれましたね.つまり＼cjkstart片方はいまいわれた ATP 再生系であろらといら見达みをとのときもいわれていた し，もう1つは遠心すれば落らる。それが 1955 年の有 名な Nature の論文(5)の骨子だったと思いますが，その ヘんはいかがだったのでしよう。

江橋＼cjkstart結局，弛緩因子は ADP キナーゼだというこ とになりつつあったのですが，こちらの弛緩因子という のは非常に熱に弱いので, Bendall がミオキナーゼだと いったときに，私は絶対違うと確信したのです。

丸山、ミオキナーゼは熱に強いわけですからね.

江橋 ええ，こちらのはちょっとした $\mathrm{pH}$ の変化で も不活性になるといらわけです. 1954年の秋ごろ，生化 学教室にインターナショナルの高速冷却遠心機が入って きたのです.そのときに, 偶然, これは本当に偶然なの です. 1948 年の Kielley と Meyerhof のペーパーを読 夕ましたら，opalescent supernatant と書いてある、私 の因子も白濁しているので，それでピンときたのです.

実は，藤田君の時代にも硫安分画をやって，分画の低 い注らに主要成分があることは見てあるのです。そのこ とはほとんど忘れていたのですが，Kielley-Meyerhof の硫安分画と一致するので, 絶対これだと信じて高速遠 心機を独占の形で 1,2 カ月, 毎日連続してやりました. それは生化学の柿内先生の専用便所にあったのです.こ の遠心機は私がこわしたという伝説になっていますが， この機会に訂正したいのですが，私の前にサインなしに 使った人がこわしたのです（笑），それで 55 年の 2 月ご らにあの論文を出しました，私としてはずいぶん早く書 き上げたものです。といらのは確信があったのでしょう。 市のペーパーについては，レフェリーだったPerryから 問い合わせがありました，非常に好意的で，喜んだわけ です. Perry は 1954 年に日本にラグビーの監督として きていまして，東大でインフォーマルなセミナーを開い たときに，丸山さんに初めて牤目にかかったのです。 ま だ大学出たばかりでしたね.

丸山、 党,まあ. 私, 出たのは 53 年ですから……
まだ子供々々した丸山さんで……55年の論 文 ${ }^{(5)}$ は, “Essential relaxing factor other than myokinase and creatine phosphokinase” といらタイトル で出したのです．これがいまのマイクロソーム・フラク ションといいますか, サルコプラズミック・レティキュ ラム・フラクションが弛緩因子であるといらことの最初 のペーパーになるわけです.

丸山補足しますと, これが認められなかったので す. ミクロソームのことがほんとうに認められるよらに なったのは 1957 年のことです. いまの熊谷, 江橋, 武 田という Nature, の論文は 55 年に出たけれど，ほとん ど無視されていて，57年になってドイッの H. H. Weber の和弟子さんの Portzehl が，グラナとかミクロソーム といらことばを使ったのです. 彼女の研究がいわゆる可 溶性分画でないという意味での最初の論文に使われてい ましたね.あれにいまの能谷，江橋の論文を正しく引用 していないのですが，あれはどらなのでしょらね.

江橋 それは彼女の偏見といらか, 自分の発見にし たいといらことでしょら。たとえば，彼女はこういら否 定のしかたをしたのです．弛緩因子がエンザイムだとい ったのは誤りだと, それはミオキナーゼなどといら意味 ではそらなのですが，そのエンザイムの中に私の論文を 入れてしまったのです. 非常に強引な論理のたて方です. 実際に学会に注目させたのは 1957 年の論文で，55 年の ペーパーはごく一部の人だけが注目したといらのがほん とうのようでした。

\section{III. カルシウム説}

丸山. カルシウムの問題にらつりたいと思います.

江橋１957年に日本でシンポジウムがありましたが， その前に, 57 年の初めか 56 年の終りだったか記憶がは っきりしませんが，弛緩因子はカルシウムをとるためで はないかといらことはチェックしてあるのですとれは， 私が迂濶だったのか，やむを得なかったのか，ちゃちな 冷凍遠心機で， 2,3 時間もかけて遠沈したもののカル シウムを化学的な方法で測ったところ，差が出なかった のでカルシウム説を放棄したのです：あのときアイソト ープと超遠心機があったら，と悔まれるのですが…....

丸山 あのときは EDTA で弛緩が起こるといら渡 辺さんや Bozler のるのは出ていたわけでしよう.

江橋出ていました，それでカルシウムだと思って 実験したらうまくゆかなかったのです，ところが；渡辺 さんたちはカルシウムを考えずに非常にむずかしい説明 をしたわけです。とにかく，カルシウムの実験がうまく 
いかなかったので, 腑に拉らないながらも, カルシウム 説は単純だからだめではないかという感じが強くなって， だんだん頭から消えていったのです.

丸山 それは測定技術の問題ですか.

江橋 そのときは測定技術の問題には違いありませ んが，確固たる見通しがあれば碩張ったはずです．それ がなかったわけです.アメリカだったら超遠心機とアイ ソトープを使らでしょらから，そのとき見つかったかも しれません．事実が出てくれば，こっちの頭のほうはす ぐ切りかわりますから．ところが，事実が出なかったか ら断念したわけです．技術的にいえば,アイソトープを 使わなかったのが手落ちです. 冷凍遠心機でもアイソト ープを使っていれば出たでしょらから.

丸山 キレート剂の作用はカルシウムがぜんぜん関 係なく, $0.6 \mathrm{M} \mathrm{KCl}$ 下でミオシン ATPase 作用をあげ るとか, あげないとかのペーパー(6)を書かれたりして， よけいなことをやって抢られましたね.

江橋 そういうわけです。

丸山 それはどこから北になったのですか。、い くつかの異なるキレート剤を使われたことは, いまから みれば非常に先駆的な仕事だったと思いますが。るちろ ん, 結果の解釈は間違っていたと思いますが……

江橋 そのとき使ったのは広告がきたからなのです. それでいろいろなキレートをしらべてみようとしたわけ です. そこは薬理学教室ですから. これは恥ずかしい話 ですが，私は GEDTA のマグネシウムに対するキレー ティングコンスタントを間違えたのです. 5.8 を 9.8 と してノートした.そのときにもし 5.8 とノートしていた ら, GEDTA が圧倒的に弛緩剤として効いたのですから, これはと気がついたはずです. それを 9.8 と写したため に全部わからなくなってしまったのです，そのときに， マグネシウムの干渉を考光てなかったのが論理的には私 の誤りですが, 5.8 が正しく写してめったらマグネシウ ムの干涉も思いついたかもしれません. 非常に顕著な事 实があれば，理くつのほらはすぐ出てきますから，とに かく, マグネシウムの干涉を考劣ないですると，カルシ ウムの結合と弛緩作用はまったく関係ないといらことに なってしまいました。

当時, GEDTA と EDTA がマグネシウムに対して結 合定数があれほど違うといらことは，まったく考えても 見ませんでした。なにか固定観念が間違った引き写しの 原因だと，いまでは考えています、いまから考劣ればま ったく迂濶な話です.こうしてカルシウム説に到達する チャンスを 2 度逃がしたわけです。
そのようなわけで, 1958 年の終わりごろにはそらい ら方向ではだめだといらので, 完全に絶望していました から，ミオシンと弛緩因子が相互作用するのではないか といら実に馬鹿げたことを考えて, 野田さんのところに 行って流動複屈折を測ってもらったら, ミオシンが突如 として並んだのです.これは弛緩因子の影響ではないか と一時思ったが, それは $\mathrm{pH}$ の間違いで, 結局ミオシン の会合をみつけたわけです. それはH. E. Huxley (1963), よりも先です.いまの言葉でいえば, ミオシンがセルフ・ アセンブリィの性格をもっているということの最初の論 文になったわけです.といらと格好がよいけれど，それ， は完全に間違いから出てきたのです，私自身はむしろ恥 ずかしくてあの論文を出すつもりはなかったけれど，野 田さんの興味には值したというので, 整理は全部野田さ. んがやってくださって日の目を見ました(7).

実は, このときの実験のアレンジは全部丸山さんがし てくださったのです.この現象の生理的意義を認めたの. は丸山さんで, あとで Huxley にこの電顕をとれと御進: 講したといら後日談があるわけです，ところで，私のほ． らは失敗つづきでほとんど筋肉をあきらめたよらな気持. でしたので, 方向転換といらことで Lipmann のところ. へ行くことになったのです. 1 つは熊谷先生の一級の人 間の所に行かなければだめだ，専門など問題ではない， というすすめに従ったわけです. もら1つは, 当時の流 行を追ってェンザイム・ケミストリーか, プロテイン合 成でもやろうと思ったのです.

丸山 第一級の人の所に行かなくてはだめだといら； 熊谷先生の信念はどこから出てきたのでしょらか.

江橋先々代の教授の田村憲造先生の影響ですね. 買物は最高のもの, 旅館でも最高の旅館に泊まる(笑). それを熊谷先生的に発展させたというわけです。そのう ちに私にロックフェラー財団のフェローシップがとれて, その役員と行き先の話をしたときに，コリンアセチラー ゼ以来頭にあったので, ついLipmann と口に出た。別 に深い気持はなかったのですが，その先生は Lipmann は人をとらないからよしたほらがよいといらので，いや， 俺は絶体に行くと碩張ったいささつから，行かざるをえ ないはめになったわけです. 当時, 熊谷先生がアメリカ に行って括られたので,すぐそのことを手紙に書いたの です. 熊谷先生は Lipmann に会ってすっかり感激され, “すわり込んでも行くべきだ”といら返事がきたわけで す. そのよらなことで Lipmann 先生のところへ行くよ. 
うになったのでまったくサイエンスとは縁遠い話です.

丸山 なぜ一級の人の話を聞いたかというと，いろ いろな歴史的なことを調べていた際に気づいたのです.

ドイッに学者の伝統といらのがあって,たとえば Liebig から始まって Kekulé, Baeyer をへて E. Fischer と Warburgにいたり，そこから Meyerhof やKrebs とい ら系統が出てきている. Krebs がまとめて書いていると ころによると，ほえとらのサイエンティストになりたけ れば, えらい人のところに行って彼がどら考えるかをみ なければいけない, それがいらばん早道である, といら ようなことをいっていて，なるほどなと思っています．

えらい人を見た人が全部えらくなるというわけでもな いが，見た人のうちで本などでは教われない何かを感じ そっていく.なるほどとうか, そういらものが学問の伝 承, あるいは伝統でしょう，そういう意味でいいますと， 江橋さんの場合は偶然そらなったというので，これはず いぶん大きな影響があるのではないか.つまり，ノーべ ル賞をもらったからえらいといらわけではないのですか ら，第一級の人であるならば何が最も重要なのかという ことがわかっていて，それを習らこと自体が，影響され やすい時代に体験するとあとに残り，かなりの影響とな りらるといらことです.

江橋妇ちろんそらです. 行く前には, Lipmannは 神さまのよらに感じていましたが, むこらに行ってもの を見る目もでき，冷静に周团の人と此較できるようにな ってからでも，やはり光らい人だといらことは変わりま せん．このごろ，ますますそらだという気持です．いろ いろな面で深い影響を受けました。

丸山 ただそこでなぜ Szent-Györgyi が出なか ったのかということですが.

江橋 やはりあの人は遠くから見るべき人だという 感じが私の中にあったのでしょう．少なくともそのとき 䛱 Szent-Györgyi といらことは頭にぜんぜん浮かんで こなかったですね. 彼が筋肉をやめていたということも あったでしよらが，しかし，彼がもし筋肉の研究をして いたとしても, やはり行かなかったでしょう。もちろん, いまでも心から尊敬していますが。

話はもとに戻りますが, Lipmann 先生に，私は何で も先生のいう通りやりますと書いたところ, “私は打前 の仕事に興味をるっている，挌前はそれをやれ”ときた のです.もらあきらめたものをまたしんどい話だなと 思って，ちょっとがっかりしましたが，そういうものか なと思って出かけたわけです，行ってみると，先生は私 のような筋肉しか知らない人間には非常に奇妙に見える
アイディアをいわれた，いまから考えると，先生の頭は すべてグループ・トランスファーといら筋金で貫かれて いるのです. 形態的に考えて，それは無理だとは思った が, チェックはこのよらにするのだといわれますので, その通りにそれをしたわけです、それがだめだったとき， Lipmann 先生は“ああ”といって，しばらくして“あと はあんたが好きなようにやれ”と、それで，その仕事は 1958 年 12 月に行きまして翌年の 3 月の初めに決着がつ いて, あとは勝手に 1 年間研究したわけです。そ点は， 一見もたもたしている扎じいてのようにみえても，キ 一・ポイントの実験をして, だめだったらだめといらの は実に早いですね. Lipmann は学問の詩人だとよくい われます、たしかにその通りで，それが人をひきつける のですが，その他に非常に頭に器用なところがあります. これは一つの秘密かもしれません。

そのころ, 3 月の初めでしたか, 図書館でSchwarzenbach のキレートの本の原著をなにげなく見ているらち にささきほど井しました，GEDTAのマグネシウムに対 するキレート定数のミスに気がついて愕然としたのです. あれ!大失敗をやったと気づいたのです，それで計算し 直したら, 完全にカルシウムのとり方と弛緩作用が並行 するのです，これは弛緩因子はカルシウムをとるに違い ない. そう思うとすべてがそう思えてくる.しかし，こ こでその仕事をやってよいかどらか思い悩んでいるとき に Lipmann 先生がやってきて, Annemarie Weber が アクトミオシン ATPase にカルシウムが必要だといっ ているがほんとらか，というのです，とれで私は，Annemarie は正しい，実は，私もこういうことをぜひさせ てほしいと思っていたのだということを， Lipmann が いいだしたのをきっかけにいいだしたのです.ところが， Lipmann 先生は“I don't think so”だけれど, 扣前が 研究したいならしてもよいということで, さっそくアイ ソトープを注文して，始めたのが 4 月半ば過ぎです，そ らしてやった最初の実験がまったく思った通りに出まし た. その第 1 回目のデータをそのまま 1962 年の Ebashi, Lipmann のペーパーにのせてあります(8). だいた い実験が思った通りにできるなどということはめったに あることでないので, “終わった”という感じでした.

ところが，私がわかるくらいだから Lipmann 先生は すぐ納得するだろうと思ったのに, “I don't think so”. それまでは, 熊谷先生があまりにも寛容で, まったくわ がままほうだいにしてきて，上の人のこわさを知らな かったのです，そのときに，えらい人を納得させるのは たいへんだ，ぞうして納得させられるだろうか。 せっか 
くここまでやりながらこれは没になるかるしれない，と いう切迫感飞襲われました。ここまで事態が進めば，そ のうちにぞこかでカルシウム説が出るでしょらからね.

丸山 その仕事については，他でその話を聞いてぱ っと発表してしまうようなこともありました。いまの話 が出版されたのは 1962 年になってからで，事実上完成 したのは 1959 年であることは私も知っています．59 年 10 月か 11 月にその話を聞いて人にちょっと話をした ら，ほかの人が 61 年にすぐペーパーを書いてしまった といら,プライオリティの侵害みたいなことがアメリカ やドイッでも起こったものですから．しかし，共著者が Lipmann だったといらので，もっているといらことが あるわけです、ほかの人ならアウトになっていますね. 文献の引用は年代順に出すのが普通なのですが, Ebashi and Lipmann 1962 年と書いて, 1961 年と書いて あります。

江橋 そこは Lipmann の威力です. 話は戻ります が，もし日本で研究していたら，日本人的な直感だけで， キー・ポイントを1つ実験したらあとは安心してしまら という悪いくせの委をで終っていたことでしょう。

その㐫とは Lipmann 先生を説得するための実験で， 4 月から11月まで夏休みの1カ月余りを除いてはその実 験に集中したわけです，そらいら意味ではきつかったで すね. 一生のらちで上の人のために苦労したのは初めて です权．西机がなかったら汪んとらに楽な一生です(笑). それだけによく䪹張りましたし，いちばん自信をもって

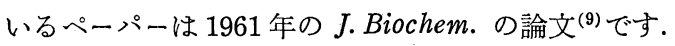
いま読んでも，個人的な感慨もあるせいでしょうが，自 分としてはよくやったといら気持です.

丸山、いま拈っしゃった論文が, Annemarie Weber と江橋のカルシウム説のキー・リファレンスになってい るものです.

江橋 しかし, Lipmann はやはりサイエンティフ ィックには納得していなかったと思います．1962年に共 著の形で出版されたときも先生の個人的な好意という感 じでした、ちょらどそのとき，いわゆる Bates 事件と いらのが起きました。これは Lipmann 先生が Bates と いら男に完全にだまされた論文を共著で出してしまった 事件なのですが，そらいった背景の中で，あのペーパー が世に出られたことは一つの人間的な問題だと思います。

Lipmann のドイッ有機化学の伝統を踏んだあのグル ープ・トランスファーについて, 信念といらか, 頑固さ は実にすごい，事実，あれだけのことをやってのけたの ですから，私のよらなものが何もいらことはないわけで
すがすすべての重要なバイオロジカル・リアクションは グループ・トランスファーであるといら観念から見れば。 カルシウムが主役一主役ではないのですが一を果た すといらことは非常に理解し難いことだといらことはよ くわかります，重要なことは，リン酸基トランスファー で起こるという信念ですね。 それで一生を貫いたわけで す。私の仕事はそういう信念の限界に触れたものとい兄 るでしょう。

\section{IV. トロポニンヘ}

丸山 そういうことでカルシウム説をめぐっていろ いろとあったのですが，そこで Annemarie Weber がア クチン側にカルシウムの效果に差があるに違いないとい ったが，彼女自身それを観察したにもかかわらず，それを 究めることはしなかった．江橋さんがそらいうディスカ ッションの間に，あなたはこの研究をするかといったら， どらぞ招やりなさいといったっつまり,Annemarie Weber は，私はそらいらような研究に向いていないのだと、は っきり私にも江橋さんにもいった，それで 1962 年に日 本へ帰ってきてから，そこにらょっとドラマチックな， 攻撃されて云々といら一幕もありましたが, 結局, アク チン側にいまのカルシウム問題があるに違いないといら ことで，何とかしてアクチンをうまくつくればカルシウ ムーセンシティブなアクトミオシンができるに違いない と，新しい研究を始められたわけでしたね。それには Annemarie Weber の影響が大きいと思います。

江橋歷史的にいえば，むしろ彼女がするべきでし ょうね。私自身はそのことをする気はなかったのです。 ところが，1962年までの筋研究の総決算ともいうべきデ ッダム（ボストン郊外）のコンファレンスで，ある人に いわれたのは、“扮前のカルシウム説は神秘的だ、なぜな ら，純粋なアクトミオシンではカルシウムは効かないこ とを知っているか”といわれ，実はとの直前に丸山さん から教わったばかりなのですが，ともかく知っていると いらと、“純粋なるのでいかないるのは神秘的だ. 生理 学者はさかんにカルシウムといらが，和前のもとの類い だ”という話で，こんちくしょうと思い，この話を解決 しなければみんながカルシウム説を信じないと思ったわ けです。

その後ニューヨークに行ったときに，Annemarie に 会って，西の研究をしたいと思うといったわけですと のときは膜に戻りたい，自分の教室の看板である薬理学 に戻りたいといら気持ちが強く, タンパク質の研究に入 るつもりはさらになかったのです，ただ，このような行 
きがかりで，もら少し続けてみようといら気になったわ けです，そこでまず考觉たことは，いままではアクチン のつくり方が悪かったのだ，よいアクチンのつくり方を あみ出とうとして始めました。弛緩因子は普通のタンパ クよりも変性しやすいので，その調製はかなりむずかし いのです、これをつくった経験からい壳ば，俺がやった ら他の人よりよいアクチンができるだろらといららぬぼ れがあって，アクチンの調製法を少し変えれば，きっと カルシウムに感受性のあるアクチンができると思ったの です．ところが，予想がはずれてもう1つのタンパクが あることがわかった，そのへん，ごちゃごちゃしたこと はたくさんありますが，これは細かい話になりますね。

丸山 1 感心しているのですが，筋肉残查の抽出 のところで徹底的に洗うことはどういうふうにしてなさ ったのですか. テクニカルといえばテクニカルですが, 長い間抽出するといら問題ですね.

江橋アクチンを室温で抽出するとトロポミオシン などがでてくることがわかっていたので，とにかく，と れるものは全部とろうといらことです. 室温でゆっくり 抽出するといらのはむしろ自然の結論でした，最初, 純 粋なアクトミオシンがカルシウムに反応しないのはア クチンの変性だと思ったのですが，そうではなく，あう 1つタンパク因子があったので，それからは变性とい ら言葉はゆめ扔らそかに使らまい，何かあったときは もら 1つタンパクがあると思らことにしました，そのと き出てきた第 3 のファクターがトロポミオシンに似てい ることから，ネイティブ・トロポミオシンといったので す(10).トロポミオシンにとらいら性質のないことがわ ったといらことで，これはもら1つファクターがあるに 違いないと信じて疑わなかったのです。これは歴史的に みると，最初ミオシンAがとれたときに変性したミオシ ンではないかといら考方方があったが，そらではなくて アクチンがあった，その次にはアクチンが変性したので はないかと思ったらネイティブ・トロポミオシンがあっ たそそらいったところから、トロポミオシンはネイティ ブ・トロポミオシンの变性物だとは，いかに碩固でも考 えないのが道理です.

といらことで,トロポニン(11 14)が出てきたわけですが， このトロポニンを分離するについては, $1 \mathrm{M} \mathrm{KCl}$ 存在下 で $\mathrm{pH} 4.6$ でトロポミオシンを沈殿させるのが最もよい トロポミオシンの精製法だ，といら丸山さんのサゼッス ションが大きいのです. このペーパーに書いてない話を
丸山さんかららかがって，その精製の逆をやったわけで す。これは仕事をしている連中からみると当り前ですが， 世間的にみると、トロポニンのほうはみながすぐアクセ プトしてくれたのですが，いちばん苦労したのは驰緩因 子です.

丸山 それはそらですね.1つにはみなが狙ってい てわからなかったこともあるでしょう，逆にいらと，日 本の科学の劣勢といったら扮かしいが，何かがあります ね.

江橋 戦時中の研究の空白のためにレベルが低かっ たし，また日本人が全体として自信を失っていましたか らね. そのような中で，いろいろな意味であれこれ迷っ たし，ずいぶん馬鹿なこともしました，目の前にありな がら逃していたとか，2，3年遅れたとかといらことす あった．自分のミスもあるし，やむをえないこともある し, 思い出深いですね.

もら1つは，あとのトロポニンの仕事のときは，自分 がするのだといら自信めいたものがあったのですが，弛 緩因子のときには，自分のしていることに意味があるだ ろらか, 間違っているのではないかといら意識のほうが 強いわけです，その意味ではきつかったですね.

1963年以後になってくると, 日本の筋肉研究も認めら れ，全体のレベルが高いといら自信がありますから，悩 んだとしてもぜいたくな悩みで，全体としての悩みは少 なかったですね。 これは日本の筋肉グループ全体がそう だろらと思います，要するに，50年代からいろいろなこ とをやった殿村さんや大沢さん，丸山さんにしても，広 く認められだして，国際的なレベルが確立してきました。 こうなると自然と自信がつくから，自分のしていること に疑いをもたなくなる．以前は自信のないことを毎日続 けているわけで，うまくいっているのに自分で迷わせて しまったのです. 1962年以後は，成果はともかくとして， 情勢はぜんぜん違ってきました。

丸山 物っしゃるのはよくわかります，江橋さんが トロポニン, トロポミオシンコンプレックスをつくって いるときの副産物として, フラクションIというのを見 いだし，それがアクトミオシンの超沈殿に不可欠ではな いかとか，収縮をさかんにするといらことをいいだした ときがありました ${ }^{(15,16)}$.これは，F-アクチンのゲル化 を执こし, 結局 $Z$ 膜の構成成分であることがわかりまし た(17)、私もアクチンをばらばらにするものを見つけて いたのでそそれと同じかどらかを検討しているらちに, アミノ酸分析の結果がアクチンとよく似ているので, ア クチニンといら名前をつけました ${ }^{(18)}$.変な名前をつけて, 
などと話をした時代もあったのです，あのときは新しい アイディアを実現しつつあるといらことで，高ぶってい たのではないかといら気もします。しかし，気がねなく， 自分たちが見つけたものはそうなんだといら，わかり合 ったものがありました。

江橋 1964〜65年ごろが日本の筋肉研究はいらばん ピークで, 66〜7 年と続いて, ちょうど停滞と大学紛争 とが一緒にきましたね．紛争で停滞したというのはいい 方に間違いがあると思います。紛争がなくても停滞して いますね。

丸山 江橋先生の仕事の場合は, 非常に注目を浴び ただけあっていろいろ批判もあり，SH がどらだとか今 日から反れば間違いの批判もありましたが，出し抜かれ たといらか, 彼らの指摘, 批判が部分的には正しかった といらこともあります，それはサイエンスですから，追 試していればありらることですが……

江橋 日本の筋研究は, 非常に苦労して登ってきた。 そのピークが $64 \sim 5$ 年ですが，そこで先の問題が出てき たわけですね。そこまでの力はあったわけですが，それ から先を仕上げるといら意味では, 長い伝統のようなる のが1つ欠けているのではないでしょらか.

大ざっぱにいうと, 日本の筋肉研究は, 65 年のときが ロスアンゼルスの水泳みたいに，何でもらまく当たって いた時代だったと思います。確かに世界中が刮目しまし た. しかし，それが汪んとらには続かなかったというこ とがありますね。思いつきないしは新しい事実が出たと き，それをきちんと固めていくことが必要なのです。そ れはイギリスの括家芸ですが，日本には伝統としてそれ がなかった，その中で，名古屋グループがそらいうるの を，あるズレはあるが，始めたという感じです。

\section{v. 反省と今後}

丸山1965年以来, 今日いうところの調節タンパク 質（レギュラートリ・プロテイン）という概念を打ち立て て，それが筋肉だけではなく，ほかの場合にるいわれる よらになっています。ここの生物学的意味はかなり大きな ことだと思っています。

江橋 レギュラートリ・プロテインというのは共通 に使われるようになりましたね。

丸山 それは江橋さんと私とがちょっと意見が対立 して，ストラクチュア・レギュラートリ・プロテインと， レギュラートリ・ストラクチュア・プロテインといらの でいい合ったことがありましたが，そのとき外国では中 をとって、レギュラートリ・プロテインといって，それ
がいま認められるようになったということがありました $\gtrless^{(19 \sim 21)}$.

そういう意味でいうと，日本人の場合には概念を立て ることを非常にちゅらちょすることるあったし………

江橋 一応そういうるのを立てることはできる。し かし，ほんとうにそうかといわれると，居直れないで退 きさがるといらわけです。

丸山 あまり大きなことを提唱することはないはず だったのですが，その点では江橋さんの見つけられたト ロポニンが，非常にきわだった作用をもっていることが 大きな意味をもっていたのです．筋肉といら特別な組織 に怙ける特別現象として出たことばではあるが，今日で は生体現象にもそれはあるに違いない，なければ探して みようといらことになりつつあります。

江橋 レギュラートリ・プロテインという感覚には エレメンタリー・プロセスが前提されている，ところが， 1つの細胞なり, システムとして全体が生理的な場でフ ァンクションするためには，エレメンタリー・プロセス だけではできない，そらいうものとのつながりですね.

丸山 仲立ちするものがあるといらことです，湯川 さんが中間子の概念を出したときに，そんな馬鹿なとい ら人もいたが，そのようなものですね.

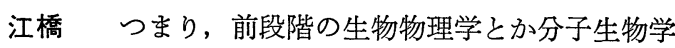
といらのは, エレメンタリー・プロセスをみつけること だった.これに対して，それらと生理現象とをつなぐも のとして，漠然とつながっているのではなくて，はっき り分子でつながっているといらことがレギュラートリ・ プロテインの概念ですね.これは生物学の人たちにはわ りあい素直に受け入れられるけれども，物理出の大沢さ んにとっては非常にインプレッシブなことだったようで す.

丸山 物理学者は素反応といらことを申しますから， 素反応ですべてが解決すると思らのでしょう，ところが, 生理現象のレベルにもってくるためには，レギュラート リ・プロテインといったアクセサリーを認めなければい けない。

江橋私自身はそれ㜔考㝋てないのに，大沢さん が非常に感心してくれるので，いささか照れているとこ ろです.

丸山 トロポニンの作用のしくみに関しては, いま 大沢さんの研究室が全力をあげている感じです.

江橋私の研究室の若い人たちは，そらいら方向と は違って，いわゆる発生生物学に傾いています.

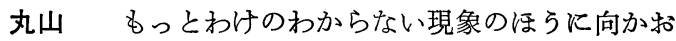


らとしている. 物理学者のほうはそのレギュラートリ・ プロテインまでは認めて…...

江橋 レギュレーションの機構に非常に興味をもち だしている。

丸山 江橋研究室は，親玉がそれだけ見つけたのだ から，その作用機作を追究してゆくのかといえばそうで はない，そのインフォメーションを基として，筋肉とい らのはどのようにして発生の過程でできるのか, という 方向に…....

江橋物理や化学の人はロジカルにオーソドックス な道を進む. 生物屋は次の問題を礼らっていくというこ とです.つまり，あるところまできたら生物屋は興味が なくなっていくのです.ですから，らちの連中はまこと に寛大なるので，このよらなむずかしいことをよくやっ たとか、これはつまらないとかいら調子で, 自分が先を 越されたという感じは毛頭ないです(笑).

丸山 それが不思議なのですが，これはある意味で おもしろいですね.

江橋私には愛惜があるから, 日本で研究してくれ るからありがたいとは思いますが，同じことなら，らち でしてくれたらよいという感じもある. その点はまこと に客観的です(笑). しかし，ある意味では健全な姿かも しれませんが，ある意味で確かに違いますね.どちらす 若い人が自由にやっているようですが, 大沢さんのとこ ろの研究室と私のところの研究室とのきわ立った体質の 違いです．私のところでは，もら終わったといらところ， それが始まりなのですね.

丸山 さて, これからの問題といらよらなことにつ いてどらでしよう.かりに，トロポニンとカルシウムの 問題を若い人との協力に抮いて, 結晶構造を解明するこ となどを一生眯命やっていくような発展のしかたもあり らるわけでしよら。

江橋 ありらると思います，ただ，そらいうことは， いまの自分の教室でやるょりも，むしろ兼任している物 理のほうでやりたいと思っています。つまり，分業だと いらことです．ただ，それではあまりにも話の笳が通り すぎているので, おむしろくないのです，筋の通ったと 話いらのは大体よいことはないのではないですか.

丸山 そこから出てきているのです. 江橋先生の拉 仕事は.

江橋近ごろの生物科学の進めかたをながめると, 何となく型にはまっているといらか, オーソドックスと いらか, 私には特もしろみがないように感じます。ちょ らど世の中が安定して社会の中での各人の持ち分がきま
ってきて，その中で自分の持ち分をやるのが正しいこと だといった気分です，たしかにその通りで，文句のいい ようはないのですが,なにか淋しいといら感じがします。 なんといらか，行きあたりばったりというか，かなり偶 然にまかせて，そのとき自分が物もしろいと思う対象に 身をまかせ，せい一杯努力してゆく，運，不運はそのま ま受げとってゆくといらふらなことでるよいのではない でしょらか. 思いつきといらのは対象に対してではなく， 自分のとる道を, いわば思いつき的にきめてゆくという ことです. もちろん, そらいう型やぶりの研究の進め方 は, 時代の流机に逆らっていることはよく承知していま すが.

\section{文献}

1) H. Kumagai, S.Ebashi \& F. Takeda : Jap. J. Pharmacol., 4, 24 (1954).

2) S. Ebashi : Jap.J.Pharmacol., 4, 32 (1954).

3) 藤田完吉：日薬理誌, 50,183 (1954).

4) 武田文子: 日薬理誌, 51, 111 (1955).

5) H. Kumagai, S. Ebashi \& F. Taked : Nature, 176, 166 (1955).

6) S. Ebashi, F. Ebashi \& Y. Fujie : J. Biochem., 47, 54 (1960).

7) H. Noda \& S. Ebashi : Biochim. Biophys. Acta, 41, 386 (1960).

8) S. Ebashi \& F. Lipmann : J. Cell Biol., 14, 389 (1962).

9) S. Ebashi : J. Biochem., 50, 236 (1961).

10) S. Ebashi \& F. Ebashi : J. Biochem., 55, 604 (1964).

11) S. Ebashi \& A. Kodama : J.Biochem., 58, $107 ; 59,425$ (1965).

12) S. Ebashi, F. Ebashi \& A. Kodama : J. Biochem., 64, 465 (1968).

13) S. Ebashi, T. Wakabayashi \& F. Ebashi : J. Biochem., 69, 411 (1971).

14) S. Ebashi : J.Biochem., in press.

15) S. Ebashi \& F. Ebashi : J.Biochem., 58, 7 (1965).

16) K. Maruyama \& S. Ebashi : J. Biochem., 58, 13 (1965).

17) T.Masaki, M.Endo \& S. Ebashi : J. Biochem., 62, 630 (1967).

18) K. Maruyama : Biochim. Biophys. Acta, 102, 542(1965).

19) K. Maruyama \& S. Ebashi : "Symp. on Muscle” ed. by E. J. Briskey, Univ. Wisconsin Press, Madison, 1970, p. 373.

20) K. Maruyama : "Muscle and Contractile Proteins", ed. by K. Laki, Dekker, New York, 1971, p. 289.

21) S. Ebashi \& Y. Nonomura : "Muscle", ed. by Bourne, Academic Press, New York, inpress.

江橋先生は, 筋肉収縮機構の研究により, 昭和 47 年度の学士院賞・恩賜賞を受賞されました。 心から特よろこび申し上げます。

(編集部) 